\title{
PHYSICOCHEMICAL PROPERTIES AND DISTRIBUTION OF NUTRIENTS ON THE INNER CONTINENTAL SHELF ADJACENT TO THE GULF OF MARANHÃO (BRAZIL) IN THE EQUATORIAL ATLANTIC
}

\author{
CAstro, A. L. C..$^{*}$ - Eschrique, S. A. ${ }^{2}-$ Silveira, P. C. A. ${ }^{2}-$ AzeVEdo, J. W. J. ${ }^{3}-$ \\ FERrEIRA, H. R. S. ${ }^{4}-$ SOARES, L. S. ${ }^{2}-$ MONTEles, J. S. ${ }^{5}-$ ArAÚJO, M. C. ${ }^{6}-$ NunES, J. L. ${ }^{3}-$ \\ SILVA, M. H. L. ${ }^{3}$ \\ ${ }^{I}$ Programa de Pós-Graduação em Saúde e Ambiente, Universidade Federal do Maranhão \\ (UFMA), Av. dos Portugueses, 1966, 65085-580 São Luís, Maranhão, Brazil \\ (phone: +55-98-3272-8563) \\ ${ }^{2}$ Departamento de Oceanografia e Limnologia, Universidade Federal do Maranhão (UFMA), \\ Av. dos Portugueses, 1966, 65085-580 São Luís, Maranhão, Brazil \\ (phone: +55-98-3272-8561) \\ ${ }^{3}$ Programa de Pós-Graduação em Biodiversidade e Biotecnologia da Amazônia Legal - Rede \\ Bionorte, Doutorado, Universidade Federal do Maranhão (UFMA), Av. dos Portugueses, 1966, \\ 65085-580 São Luís, Maranhão, Brazil \\ (phone: +55-98-3272-8563) \\ ${ }^{4}$ Programa de Pós-Graduação em Oceanografia, Mestrado, Universidade Federal do \\ Maranhão (UFMA), Av. dos Portugueses, 1966, 65085-580 São Luís, Maranhão, Brazil \\ (phone: +55-98-3272-8563) \\ ${ }^{5}$ Programa de Pós-Graduação em Ciências Ambientais, Mestrado, Universidade Federal do \\ Pará, Rua Augusto Corrêa, 01, 66075-110 Belém, Pará, Brazil \\ ${ }^{6}$ Laboratório de Oceanografia Física Estuarina e Costeira (LOFEC), Departamento de \\ Oceanografia, Universidade Federal de Pernambuco, Av. da Arquitetura s/n, 50740-540 Recife, \\ Pernambuco, Brazil \\ *Corresponding author \\ e-mail:alec@ufma.br; phone: +55-98-3272-8563 \\ (Received $17^{\text {th }}$ May 2018; accepted $11^{\text {th }}$ Jul 2018)
}

\begin{abstract}
The dynamics of the physical and chemical factors that regulate oceanographic processes on the continental shelf off the state of Maranhão (northeastern Brazil) was evaluated using a transect along São Marcos Bay $\left(01^{\circ} 41^{\prime} \mathrm{S}-02^{\circ} 28^{\prime} \mathrm{S}\right.$ and $\left.43^{\circ} 47^{\prime} \mathrm{W}-44^{\circ} 13^{\prime} \mathrm{W}\right)$ in January, March, May, July and September 2014, with a total of seven sampling stations. Water samples were collected from the surface using a Van Dorn water sampler. The following hydrochemical variables were analyzed: water transparency $(\mathrm{m})$, temperature $\left({ }^{\circ} \mathrm{C}\right)$, salinity, conductivity $\left(\mathrm{mS} \mathrm{cm}^{-1}\right)$, total dissolved solids (TDS, $\left.\mathrm{g} \mathrm{L}^{-1}\right)$, $\mathrm{pH}$, dissolved oxygen ( $\mathrm{mg} \mathrm{L}^{-1}$ ), turbidity (NTU), total suspended solids (TSS) and dissolved nutrients (phosphate, nitrite and silicate). The relationship between these variables and seasonality in the region [rainy season (January to June) and dry season (July to December)] were also evaluated. For data with normality and equal variances, a one-way analysis of variance (ANOVA) was used for the spatial and temporal comparisons of the physicochemical variables. Results showed that the spatial and temporal variability of the physicochemical variables analyzed in this study is associated with local dynamics governed by river discharge, tidal movements, currents and meteorological events. The fluvial transport from the rivers of the state of Maranhão and other freshwater sources in the Amazon region are apparently the major contributors responsible for the maintenance of nutrient availability on the Maranhão continental shelf.
\end{abstract}


The present paper aims to broaden the knowledge of the spatial and temporal variability in the physicochemical variables in continental shelves and adjacent waters the coast of Maranhão (North Brazil).

Keywords: surface water masses, hydrochemical variables, spatial distribution, dissolved nutrients, biogeochemical activity, influence of the discharge freshwater

\section{Introduction}

The continental shelf is an environment with strong biogeochemical activity due to matter transported from land combined with water-sediment interactions and processes of biological absorption, respiration and re-mineralization. Coastal waters receive sediments and discharge from freshwater and underground sources and are therefore more affected by human activities than the open ocean (Lefèvre et al., 2017).

Physicochemical variables are often used to characterize masses of water along continental shelves and adjacent coastal waters and are also important to the determination of biogeochemical processes in response to land and oceanic inputs (Braga et al., 2008). The dynamics of the physical and chemical factors that regulate oceanographic processes on the continental shelf off the state of Maranhão (northeastern Brazil) are not yet fully understood, especially those related to small-scale and mediumscale events governed by freshwater discharge, wave energy, trade winds, macro-tide patterns and the Intertropical Convergence Zone (ITCZ).

The seasonal cycle of the migration of the ITCZ in the tropical Atlantic reflects the behavior and position of surface currents (Stramma and Scott, 1999). The mesoscale circulation in the region of the continental shelf off the state of Maranhão is strongly influenced by the North Brazil Current, directly affecting the spread of the plume of the Amazon River (Nikiema et al., 2007). This cyclic phenomenon alters physicochemical properties and the concentration of nutrients in coastal waters of the São Marcos Estuarine Complex and controls the distribution and abundance of migrant fishing resources in the Gulf of Maranhão.

It is presumed that freshwater discharge from the São Marcos Estuarine Complex serves as an obstacle to the advance of lower temperature marine waters, while also exerting a strong influence on the input and redistribution of nutrients on the inner continental shelf. Thus, the determination of these variables would enable an understanding of the variability in the structure of surface water masses and contribute knowledge on the complex hydrodynamics of the Gulf of Maranhão.

The present paper aim to broaden the knowledge of the spatial and temporal variability in the physicochemical variables in continental shelf and adjacent waters the coast of Maranhão (North Brazil), associated with local dynamics governed by river discharge, tidal movements, currents and weather events.

\section{Material and methods}

\section{Study area}

The coastal region of the state of Maranhão is classified as being on the northern coast of Brazil, based mainly on the morphology of the coast, climate, oceanographic variables, sediment coverage and width of the continental shelf. This stretch of the coast has been subdivided into three sectors form corresponding to the coast of Maranhão on the eastern Amazonian coast, with a large number of small estuaries bordered by hills 
formed by tertiary sediments of the Barreiras Formation, currently in complete regression (El Robrini et al., 2006). Mangroves occur in protected areas, accentuating the irregularities of the coastline and generating broad tidal plains (Mochel and Ponzoni, 2007).

The coast of Maranhão extends $640 \mathrm{~km}$, with a wide continental shelf and relatively shallow waters under the influence of the discharge of a large number of rivers. The physical characteristics of the coastline enable a division into two distinct parts. The first extends from the border of the state of Pará to Tubarão Bay and is characterized by a low coast of mangroves and deep indentations forming a series of bays and estuaries (denominated the Reentrâncias Maranhenses). The second area extends from Tubarão Bay eastward to the mouth of the Parnaíba River. In this area, the coastline is regular and part is covered by a vast area of sand dunes, denominated the Lençóis Maranhenses.

The Gulf of Maranhão is located in the center of the coast and is where São Luís Island is located, which separates the gulf into two large bays. São Marcos Bay lies to the west, which is an active estuary where the Mearim and Pindaré Rivers converge. The most intense tides are recorded in the mouth of this bay. São José Bay to the east of the island is a region with shallow depths that receives waters from the Itapecuru and Munim rivers (Silva et al., 2018). Off the Gulf of Maranhão, the continental shelf has a mean width of $150 \mathrm{~km}$ and depths less than $45 \mathrm{~m}$, reaching a depth of $75 \mathrm{~m}$ near the break of the shelf and dropping abruptly to $2.000 \mathrm{~m}$ at the base of the continental slope (Silva and Alvarenga, 1994).

The Maranhão continental shelf can be classified as a high-energy region due to the combined effects of the coastal currents generated by different hydrodynamic forces, such as tides, waves, trade winds and the discharge of the Itapecuru/Munim rivers and Pindaré/Mearim rivers that respectively form the São José Estuarine Complex and São Marcos Estuarine Complex. The volume transported from the Pindaré/Mearim Rivers to the São Marcos Estuarine Complex corresponds to $10 \mathrm{~km}^{3}$ per year (Jennerjahn et al., 2010), with maximum discharge occurring in March/April, which is the peak of the rainy season.

\section{Data collection}

Data were obtained from a transect determined in São Marcos Bay $\left(01^{\circ} 41^{\prime} \mathrm{S}-02^{\circ} 28^{\prime} \mathrm{S}\right.$ and $43^{\circ} 47^{\prime} \mathrm{W}-44^{\circ} 13^{\prime} \mathrm{W}$ ) in January, March, May, July and September 2014, involving seven sampling stations (Fig. 1). Station 1 was located near the city of São Luís and Station 7 was located on the continental shelf before the 50-meter isobath at approximately $100 \mathrm{~km}$ from Station 1.

Water samples were collected from the surface using a van Dorn hydrographic bottle. The following hydrochemical variables were determined in the field: water transparency, measured by the depth of the disappearance of the Secchi disk (m); temperature $\left({ }^{\circ} \mathrm{C}\right)$, salinity $\left(\mathrm{g} \mathrm{kg}^{-1}\right)$, conductivity $\left(\mathrm{mS} \mathrm{cm}^{-1}\right)$, total dissolved solids (TDS, $\mathrm{g} \mathrm{L}^{-1}$ ) and $\mathrm{pH}$, using a HANNA HI-9828 multiparameter probe; dissolved oxygen (mg $\mathrm{L}^{-1}$ ), using a HANNA HI-9146 oximeter together with the Winkler analytical method, as cited in Strickland and Parsons (1972); and turbidity (NTU), using a Tecnopon TB1000® turbidity meter. For the determination of total suspended solids (TSS), water samples were kept refrigerated at $-4{ }^{\circ} \mathrm{C}$ until filtered and analyzed in the laboratory. TSS (mg L ${ }^{-1}$ ) was measured using the gravimetric method, as described in APHA 
(2001). Dissolved nutrients (phosphate, nitrite and silicate) were determined using the method described by Grasshoff et al. (1999).

Climatologic data were acquired from the databank available by INMET (Brazilian Meteorological Institute) recorded by the São Luis meteorological station.

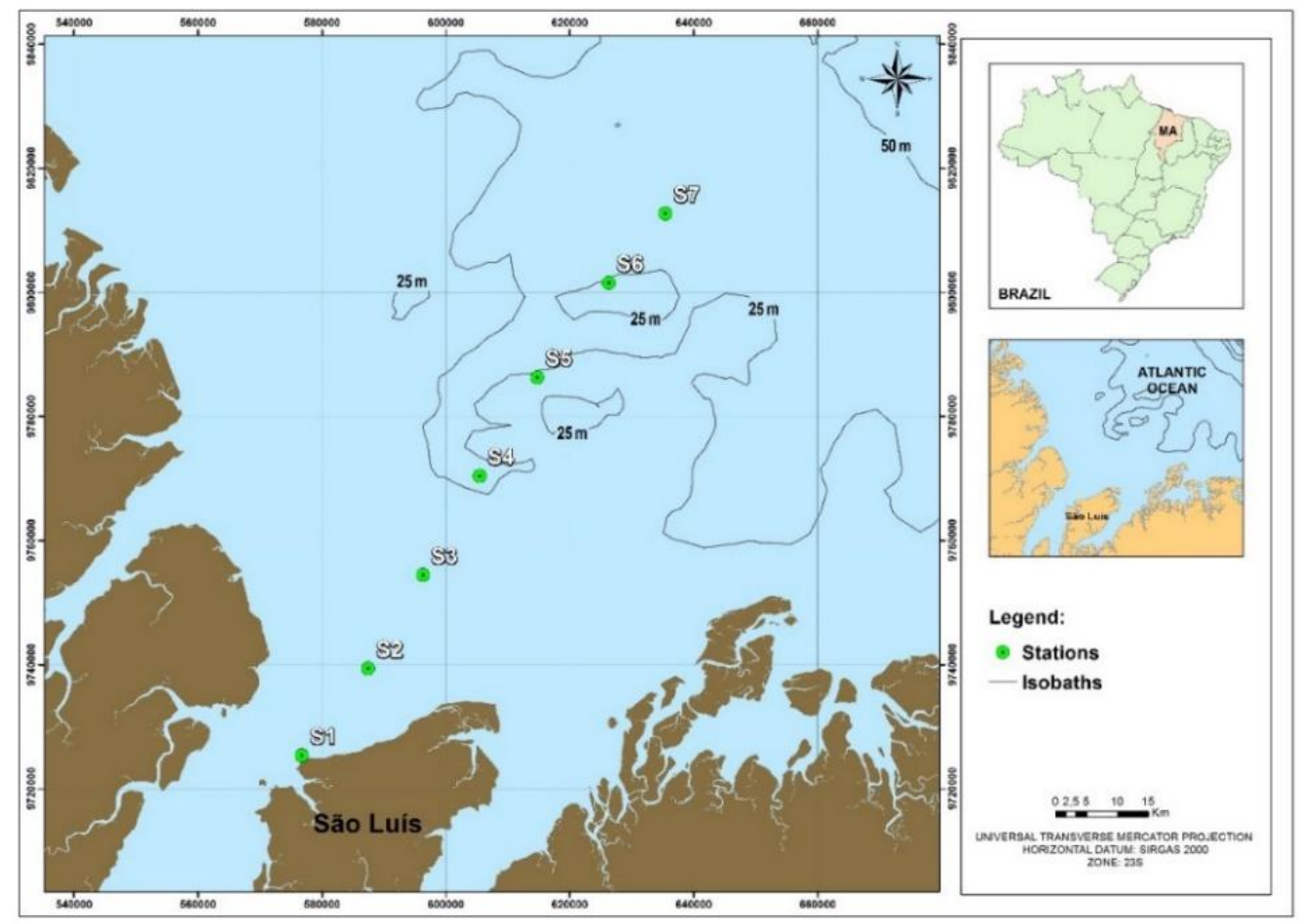

Figure 1. Location of sampling stations along transect on continental shelf off state of Maranhão

\section{Data analysis}

The physical and chemical variables were expressed as mean, standard deviation, minimum and maximum values determined for each sampling period. The relationship between these variables and seasonality in the region [rainy season (January to June) and dry season (July to December)] were also evaluated. The Shapiro-Wilk test and Levene's test were used to determine the normality of the data distribution and equal variance, respectively. For data with equal variances, one-way analysis of variance (ANOVA) was used for the spatial and temporal comparisons of the physicochemical variables. In cases for which the null hypothesis of variance was rejected, a multicomparison test (Tukey's test) was used to identify which pairs of means differed significantly. For data with unequal variances, the spatiotemporal comparisons were made using the Kruskal-Wallis $(\mathrm{H})$ test, followed by the Mann-Whitney U test when the null hypothesis was rejected. Principal component analysis was used to identify the main components responsible for the variations in the data on the Maranhão continental shelf, using the correlation matrix as the basis. The significance of Pearson's correlation table was calculated using a two-tailed $t$-test with two degrees of freedom. Excel 2010 and PAST 3.14 were used for the data analysis as well as the creation of the graphs and tables (Hammer et al., 2001). The statistical analyses were evaluated for a critical significance level of $\alpha=0.05$ (Zar, 2010). 


\section{Results}

\section{Hydrological conditions}

The accumulated monthly rainfall for 2014 at Station 1 showed values always higher than $100 \mathrm{~mm}$ in the months of January to June (Fig. 2). In the oceanic region, the precipitation followed the same seasonal cycle compared to the coastal region, with usually slightly lower accumulated rainfall values. The INMET data gave higher rainfall during the wet season. The wet season was associated with the presence of the ITCZ located at its southernmost position in March-April.

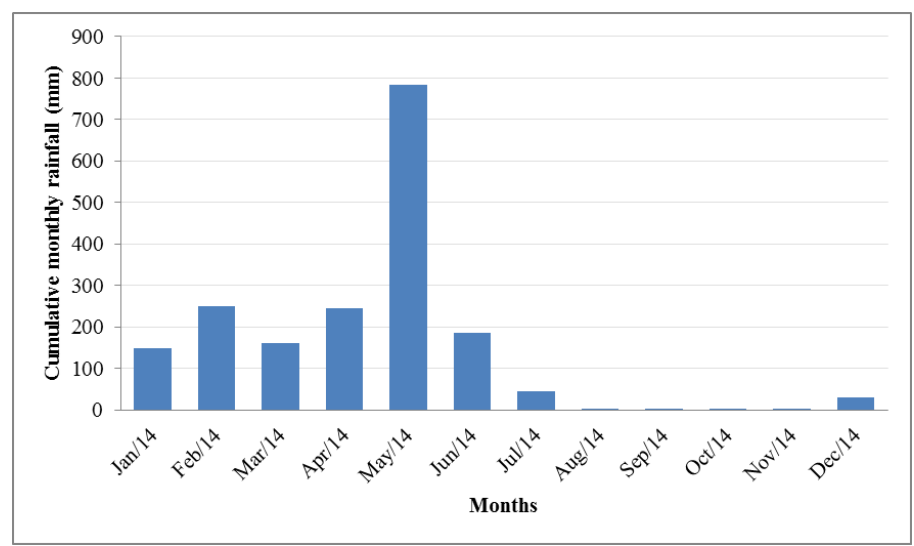

Figure 2. Accumulated monthly rainfall for 2014 at Station 1 (São Luís, Maranhão). (Source: BDMEP, INMET)

\section{Abiotic variables}

Table 1 displays the mean, standard deviation, maximum and minimum values for the physical and chemical variables of the surface waters measured on the Maranhão continental shelf. Water surface temperature ranged from $27.37{ }^{\circ} \mathrm{C}$ to $30.33{ }^{\circ} \mathrm{C}$, corresponding to the wet and dry seasons, respectively (Fig. 3a). The mean for all months analyzed was $28.7^{\circ} \mathrm{C}$, which reflects the characteristic of the equatorial region, with small horizontal variations, mean amplitude of approximately $1{ }^{\circ} \mathrm{C}$ in the rainy season and $2{ }^{\circ} \mathrm{C}$ in the dry season. In statistical terms, temperatures were significantly lower in September $2014(\mathrm{H}=14.59$; $\mathrm{p}<0.0001)$, but with no significant differences among the different sampling stations $(\mathrm{F}=1.61 ; \mathrm{p}>0.05)$.

The spatial distribution of salinity (Fig. $3 b$ ) ranged from $25.95 \mathrm{~g} \mathrm{~kg}^{-1}$ to $38.08 \mathrm{~g} \mathrm{~kg}^{-1}$ throughout the study. The means per station were 30.98, 32.11, 34.64, 35.39, 35.91, 36.28 and $36.14 \mathrm{~g} \mathrm{~kg}^{-1}$ for S1, S2, S3, S4, S5, S6 and S7, respectively.

A progressive increase in salinity was found with the increase in distance from the coast, with significantly higher values at Stations 5, 6 and 7 in comparison to Station 1 $\left(\mathrm{F}=4.22 ; \mathrm{p}<0.05\right.$. Mean salinity was $35.04 \mathrm{~g} \mathrm{~kg}^{-1}$ in the rainy season and $33.68 \mathrm{~g} \mathrm{~kg}^{-1}$ in the dry season, with significantly higher values in January $2014(\mathrm{Hc}=16.33$; $\mathrm{p}<0.0001)$. In May 2014, the lowest salinity was found at Station $1\left(25.95 \mathrm{~g} \mathrm{~kg}^{-1}\right)$, which contributed to the mean value in the rainy season $\left(32.2 \mathrm{~g} \mathrm{~kg}^{-1}\right)$ and coincides with the period of greater rainfall intensity in the region, with an accumulated rainfall of $784.3 \mathrm{~mm}$ in May 2014. The highest mean salinity was found in January 2014 $\left(36.72 \mathrm{~g} \mathrm{~kg}^{-1}\right)$, which was likely due to the low rainfall in the final trimester of the previous year. 

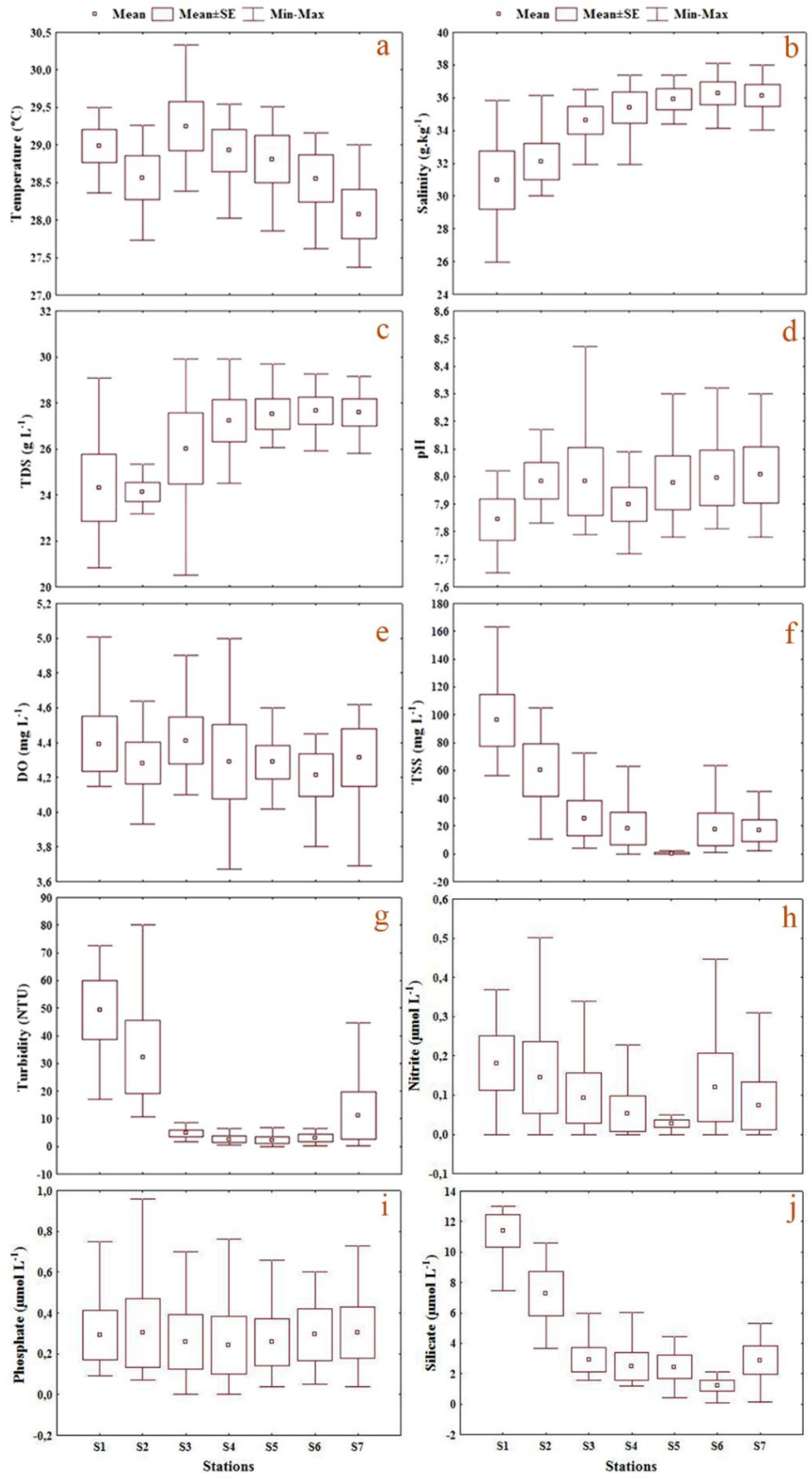

Figure 3. Spatial distribution of physical and chemical variables of the surface waters along Maranhão continental shelf in each sampling station. $a$ - temperature, $b$ - salinity, $c-T D S, d$ $p H, e$-DO, $f$-TSS, $g$ - turbidity, $h$ - nitrite, $i$ - phosphate, $j$ - silicate 
Table 1. Mean, standard deviation, maximum and minimum values of physical and chemical variables collected on Maranhão continental shelf throughout study period

\begin{tabular}{|c|c|c|c|c|c|c|c|c|c|c|c|c|c|}
\hline Period & \begin{tabular}{|c|} 
Descriptive \\
statistic
\end{tabular} & $\begin{array}{c}\text { Temp } \\
\left({ }^{\circ} \mathrm{C}\right)\end{array}$ & \begin{tabular}{|c|} 
Sal \\
$\left(\mathrm{g} \mathrm{kg}^{-1}\right)$
\end{tabular} & \begin{tabular}{|c|} 
TDS \\
$\left(\mathrm{g} \mathrm{L}^{-1}\right)$ \\
\end{tabular} & $\begin{array}{c}\text { Cond } \\
\left(\mathrm{mS} \mathrm{cm}^{-1}\right)\end{array}$ & pH & $\begin{array}{c}\text { DO } \\
\left(\mathrm{mg} \mathrm{L}^{-1}\right) \\
\end{array}$ & \begin{tabular}{|c|}
$\begin{array}{c}\text { Secchi } \\
(\mathbf{m})\end{array}$ \\
\end{tabular} & \begin{tabular}{|c|}
$\begin{array}{c}\text { Turb } \\
\text { (NTU) }\end{array}$ \\
\end{tabular} & $\begin{array}{c}\text { TSS } \\
\left(\mathrm{mg} \mathrm{L}^{-1}\right)\end{array}$ & $\begin{array}{c}\mathrm{SiO}_{2} \\
\left(\mu \mathrm{mol} \mathrm{L}^{-1}\right) \\
\end{array}$ & $\begin{array}{c}\mathrm{PO}_{4}{ }^{3-} \\
\left(\mu \mathrm{mol} \mathrm{L}^{-1}\right)\end{array}$ & $\begin{array}{c}\mathrm{NO}_{2-} \\
\left(\mu \mathrm{mol} \mathrm{L}^{-1}\right)\end{array}$ \\
\hline \multirow{4}{*}{ Jan/14 } & Mean & 28.84 & 36.72 & 28.82 & 57.40 & 8.11 & 4.12 & 4.26 & 17.80 & 21.43 & 3.75 & 0.05 & 0.05 \\
\hline & Deviation & 0.72 & 0.61 & 1.83 & 4.20 & 0.19 & 0.12 & 3.50 & 24.45 & 31.78 & 4.06 & 0.02 & 0.05 \\
\hline & Maximum & 29.50 & 37.39 & 29.90 & 59.80 & 8.32 & 4.30 & 10.37 & 72.50 & 91.00 & 12.78 & 0.09 & 0.15 \\
\hline & Minimum & 27.73 & 35.84 & 24.75 & 48.01 & 7.92 & 3.93 & 0.13 & 6.05 & 1.00 & 1.51 & 0.03 & 0.00 \\
\hline \multirow{4}{*}{ Mar/14 } & Mean & 28.90 & 36.20 & 27.48 & 54.62 & 7.81 & 4.16 & 5.07 & 19.57 & 29.14 & 4.73 & 0.11 & 0.07 \\
\hline & Deviation & 0.36 & 2.22 & 1.57 & 3.57 & 0.07 & 0.21 & 3.52 & 33.13 & 45.77 & 4.98 & 0.03 & 0.10 \\
\hline & Maximum & 29.50 & 38.08 & 28.68 & 57.36 & 7.87 & 4.27 & 8.20 & 80.00 & 100.00 & 12.99 & 0.15 & 0.27 \\
\hline & Minimum & 28.57 & 32.78 & 25.35 & 48.37 & 7.72 & 3.69 & 0.26 & 0.13 & 0.00 & 0.92 & 0.07 & 0.00 \\
\hline \multirow{4}{*}{ May/14 } & Mean & 29.28 & 32.19 & 24.19 & 48.56 & 8.11 & 4.51 & 7.57 & 9.16 & 19.53 & 5.76 & 0.52 & 0.06 \\
\hline & Deviation & 0.20 & 3.44 & 2.77 & 5.55 & 0.24 & 0.39 & 5.48 & 11.00 & 27.09 & 3.41 & 0.28 & 0.09 \\
\hline & Maximum & 29.54 & 35.60 & 27.03 & 53.84 & 8.47 & 5.00 & 15.26 & 33.00 & 70.00 & 12.85 & 0.76 & 0.23 \\
\hline & Minimum & 29.00 & 25.95 & 20.51 & 40.61 & 7.65 & 3.80 & 0.41 & 2.40 & 0.00 & 2.14 & 0.09 & 0.00 \\
\hline \multirow{4}{*}{$\mathrm{Jul} / 14$} & Mean & 28.66 & 33.75 & 25.74 & 51.49 & 7.89 & 4.54 & 6.31 & 19.53 & 65.17 & 4.77 & 0.16 & 0.32 \\
\hline & Deviation & 0.95 & 3.30 & 2.25 & 4.50 & 0.15 & 0.24 & 4.94 & 27.09 & 51.34 & 3.70 & 0.13 & 0.15 \\
\hline & Maximum & 30.33 & 36.26 & 27.42 & 54.85 & 8.17 & 5.01 & 12.00 & 70.00 & 163.00 & 10.84 & 0.33 & 0.50 \\
\hline & Minimum & 27.37 & 28.14 & 21.90 & 43.80 & 7.78 & 4.30 & 0.22 & 0.00 & 0.00 & 1.43 & 0.00 & 0.05 \\
\hline \multirow{4}{*}{ Sep/14 } & Mean & 28.00 & 33.61 & 25.51 & 51.02 & 7.86 & 4.24 & 3.46 & 9.27 & 32.23 & 2.87 & 0.55 & 0.00 \\
\hline & Deviation & 0.40 & 1.43 & 0.95 & 1.90 & 0.03 & 0.28 & 2.86 & 15.43 & 36.93 & 3.79 & 0.23 & 0.00 \\
\hline & Maximum & 28.38 & 34.98 & 26.35 & 52.70 & 7.89 & 4.49 & 7.70 & 41.50 & 104.81 & 9.18 & 0.96 & 0.00 \\
\hline & Minimum & 27.37 & 31.48 & 24.08 & 48.17 & 7.82 & 3.67 & 0.14 & 0.15 & 0.00 & 0.08 & 0.35 & 0.00 \\
\hline
\end{tabular}

On the Maranhão continental shelf, total dissolved solids (TDS) ranged from $20.51 \mathrm{~g} \mathrm{~L}^{-1}$ to $29.90 \mathrm{~g} \mathrm{~L}^{-1}$, with means of $25.62 \mathrm{~g} \mathrm{~L}^{-1}$ and $26.83 \mathrm{~g} \mathrm{~L}^{-1}$ in the dry and rainy seasons, respectively (Fig. 3c). In statistical terms, TDS demonstrated similar patterns to salinity, with higher concentrations in January $2014(\mathrm{~F}=6.05 ; \mathrm{p}<0.00)$. The value at Station 2 was significantly lower in comparison to the values found at Stations 4, 5, 6 and $7(\mathrm{~F}=2.54 ; \mathrm{p}<0.05)$.

The $\mathrm{pH}$ values remained basic, ranging from 7.65 to 8.47 throughout the study, with a mean of 8.01 in the rainy season and 7.88 in the dry season (Fig. 3d). Values were higher in January 2104 compared to March and September $2014(\mathrm{~F}=5.97$; $\mathrm{p}<0.0001)$.

Dissolved oxygen (DO) concentrations ranged from $3.67 \mathrm{mg} \mathrm{L}^{-1}$ to $5.01 \mathrm{mg} \mathrm{L}^{-1}$, with a mean of $4.26 \mathrm{mg} \mathrm{L}^{-1}$ in the rainy season and $4.39 \mathrm{mg} \mathrm{L}^{-1}$ in the dry season (Fig. 3e). The seasonal and spatial distribution of DO demonstrated similar concentrations, indicating a homogeneous pattern for this variable throughout the Maranhão continental shelf.

Spatial distribution of total suspended solids (TSS) concentrations ranged from $0.40 \mathrm{mg} \mathrm{L}^{-1}$ to $163.00 \mathrm{mg} \mathrm{L}^{-1}$, with mean concentrations from $23.37 \mathrm{mg} \mathrm{L}^{-1}$ in the rainy season to $48.70 \mathrm{mg} \mathrm{L}^{-1}$ in the dry seasons, with no statistically significant difference (Fig. 3f). Higher concentrations of TSS were found near the coast, with a progressive reduction toward oceanic regions, especially during the campaigns performed in the dry season. The highest concentration was $163.00 \mathrm{mg} \mathrm{L}^{-1}$ at Station 1, which differed significantly from all other stations $(H=21.02 ; \mathrm{p}<0.0001)$, except Station 2 . The finding suggests the influence of inputs from the mainland combined with tide dynamics.

Turbidity ranged from $0.13 \mathrm{NTU}$ to $80.00 \mathrm{NTU}$, with a mean of $15.51 \mathrm{NTU}$ in the rainy season and 14.40 NTU in the dry season, demonstrating no significant seasonal 
difference (Fig. 3g). A spatial gradient was found during all sampling campaigns, with greater turbidity near the coast (Stations 1 and 2) and a progressive reduction toward the oceanic region to values close to $0(\mathrm{H}=20.4 ; \mathrm{p}<0.0001)$. Such a pattern was expected due to the influence of total suspended solids and organic matter due to river discharge and the influence of the estuarine plume.

The spatial distribution of nitrite in the surface waters of the Maranhão continental shelf showed a maximum of $0.50 \mu \mathrm{mol} \mathrm{L}{ }^{-1}$. The highest values were found in July 2014 $(\mathrm{H}=17.6 ; \mathrm{p}<0.0001)$, probably due to the advance of the estuarine plume toward the continental shelf. This is corroborated by the increase in organic and inorganic mater demonstrated by the variations in TSS and turbidity, which were higher at the end of the rainy season. Nitrite concentrations were lower than $1 \mu \mathrm{mol} \mathrm{L}{ }^{-1}$ at all sampling stations (Fig. 3h).

Phosphorus concentrations ranged from $0.03 \mu \mathrm{mol} \mathrm{L} \mathrm{L}^{-1}$ to $0.96 \mu \mathrm{mol} \mathrm{L} \mathrm{L}^{-1}$, with a mean of $0.23 \mu \mathrm{mol} \mathrm{L}^{-1}$ in the rainy season and $0.35 \mu \mathrm{mol} \mathrm{L}{ }^{-1}$ in the dry season (Fig. 3i). Small variations in phosphate concentration were found during the sampling campaigns, with significantly higher concentrations in May $2014\left(0.52 \pm 0.28 \mu \mathrm{mol} \mathrm{L}^{-1}\right)$ and September $2014\left(0.55 \pm 0.23 \mu \mathrm{mol} \mathrm{L}^{-1}\right)(\mathrm{H}=22.5 ; \mathrm{p}<0.0001)$, likely due to the contributions of river runoff and rainfall. In spatial terms, no significant differences were found throughout the sampling stations along the Maranhão continental shelf.

Silicate concentrations ranged from $0.08 \mu \mathrm{mol} \mathrm{L}^{-1}$ to $12.99 \mu \mathrm{mol} \mathrm{L} \mathrm{L}^{-1}$, with a mean of $4.75 \mu \mathrm{mol} \mathrm{L}^{-1}$ in the rainy season and $3.82 \mu \mathrm{mol} \mathrm{L}^{-1}$ in the dry season (Fig. $3 j$ ). Although this transport is evidenced on the Maranhão continental shelf by the increase in rainfall, however no statistically significant difference was found $(\mathrm{F}=0.52$; $\mathrm{p}=0.72$ ), demonstrating a lack of seasonal heterogeneity with regard to the concentration of silicate. On the spatial scale, however, sampling stations closer to the coast (Stations 1 and 2) had higher silicate concentrations throughout all campaigns $(\mathrm{F}=14.83 ; \mathrm{p}<0.0001)$, which was likely due to the strong influence of rainfall and river discharge. Data from the Analysis of Variance (Table 2) show the significance of the physicochemical variables in relation to the months and sampling sites.

In the principal component analysis of the environmental variables, the first two axes explained $58.3 \%$ of the variability in the data (Fig. 4). The significance of the axes was tested using the "broken stick" random model with 9999 bootstrap replicates (Jackson, 1993), which indicated that Components 1 and 2 were sufficient to represent the factorial variance.

Component $1(41.1 \%)$ was positively related to turbidity, total suspended solids, silicate, dissolved oxygen and phosphate, with a tendency toward higher values in the rainy months (January, March and May) as well as at sampling sites closer to the coast, especially Stations 1 and 2. Although July and September are considered to be part of the dry season, both months apparently demonstrated the influence of adjacent drainage stemming from rainfall in the previous months, leading to the maintenance of high turbidity, suspended solids, DO, silicate and nitrite.

Component 1 was negatively correlated with TDS, conductivity, salinity and transparency, with an absence of a pattern in seasonal terms and an expected increase in values at sampling sites more distant from the coast (Stations 3, 4, 5, 6 and 7), which are characterized by greater transparency and dissolved minerals.

Component $2(17.2 \%)$ was negatively correlated with phosphate $\left(\mathrm{PO}_{4}{ }^{3-}\right)$ and $\mathrm{pH}$. Phosphate was associated more with May and September. Moreover, the similar distribution throughout the sampling stations suggests the absorption of this nutrient, 
making its concentration quite homogeneous throughout the Maranhão continental shelf. $\mathrm{pH}$ was associated more with May, when the highest values were found, as well as sampling sites more distant from the coast (Stations 5, 6 and 7), which is an expected pattern due to the alkaline tendency of oceanic water.

Table 2. Results of ANOVA the physicochemical variables in the spatial temporal scale. The equal letters represent statistical similarity at the level of 5\% of significance, considering each one of the parameters in function of the months and the sampling stations

\begin{tabular}{|c|c|c|c|c|c|c|c|c|c|c|c|c|}
\hline \multirow{2}{*}{ Variables } & \multicolumn{5}{|c|}{ Months of sampling } & \multicolumn{7}{|c|}{ Sampling stations } \\
\hline & Jan/14 & Mar/14 & May/14 & Jul/14 & Sep/14 & S1 & S2 & S3 & S4 & S5 & S6 & S7 \\
\hline & & $28,9^{\mathrm{a}}$ & $29,28^{\mathrm{a}}$ & $28,67^{\mathrm{ab}}$ & $28^{\mathrm{b}}$ & $800^{a}$ & $28,56^{\mathrm{a}}$ & $29,25^{\mathrm{a}}$ & $28,93^{\mathrm{a}}$ & $28,81^{\mathrm{a}}$ & $28,55^{\mathrm{a}}$ & $28,08^{\mathrm{a}}$ \\
\hline Sal $\left(\mathrm{g} \mathrm{kg}^{-1}\right)$ & $6,72^{\mathrm{a}}$ & $36,19^{\mathrm{ac}}$ & $32,19^{\mathrm{b}}$ & $33,75^{\mathrm{bc}}$ & $33,61^{\mathrm{bc}}$ & $30,98^{\mathrm{a}}$ & $32,11^{\mathrm{ab}}$ & $34,64^{\mathrm{ab}}$ & $35,39^{\mathrm{ab}}$ & $35,91^{\mathrm{b}}$ & $36,28^{\mathrm{b}}$ & $36,14^{\mathrm{b}}$ \\
\hline $\operatorname{TDS}\left(\mathrm{g} \mathrm{L}^{-1}\right)$ & $28,81^{\mathrm{a}}$ & $27,48^{\mathrm{ac}}$ & $24,19^{b}$ & $25,73^{\mathrm{bc}}$ & $25,51^{\mathrm{bc}}$ & $24,32^{\mathrm{ac}}$ & $24,13^{\mathrm{a}}$ & $25,61^{\text {ac }}$ & $27,23^{\mathrm{bc}}$ & $27,51^{\mathrm{bc}}$ & $27,66^{\text {bc }}$ & $27,59^{\mathrm{bc}}$ \\
\hline pH & $8,11^{\mathrm{a}}$ & $7,81^{\mathrm{b}}$ & $8,11^{\mathrm{a}}$ & $7,89^{\mathrm{ab}}$ & $7,86^{\mathrm{b}}$ & $7,84^{\mathrm{a}}$ & $7,98^{\mathrm{a}}$ & $7,98^{\mathrm{a}}$ & $7,89^{\mathrm{a}}$ & $7,98^{\mathrm{a}}$ & $7,99^{\mathrm{a}}$ & $8,01^{\mathrm{a}}$ \\
\hline$O D\left(\mathrm{mg} \mathrm{L}^{-1}\right)$ & $4,11^{\mathrm{ac}}$ & $4,15^{\mathrm{c}}$ & $4,51^{\mathrm{c}}$ & $4,54^{\mathrm{b}}$ & $4,24^{\mathrm{c}}$ & $4,39^{\mathrm{a}}$ & $4,28^{\mathrm{a}}$ & $4,41^{\mathrm{a}}$ & $4,29^{\mathrm{a}}$ & $4,29^{\mathrm{a}}$ & $4,21^{\mathrm{a}}$ & $4,31^{\mathrm{a}}$ \\
\hline Secchi (m) & $4,26^{\mathrm{a}}$ & $5,07^{\mathrm{a}}$ & $7,57^{\mathrm{a}}$ & $6,31^{\mathrm{a}}$ & $3,46^{\mathrm{a}}$ & $0,23^{\mathrm{a}}$ & $0,704^{\mathrm{b}}$ & $3,988^{\mathrm{c}}$ & $5,728^{\mathrm{cd}}$ & $7,428^{\text {cde }}$ & $8,56^{\mathrm{de}}$ & $10,71^{\mathrm{e}}$ \\
\hline Turb (NTU) & $17,8^{\mathrm{a}}$ & $19,56^{\mathrm{a}}$ & $9,16^{\mathrm{a}}$ & $19,53^{\mathrm{a}}$ & $9,27^{\mathrm{a}}$ & $49,22^{\mathrm{a}}$ & $32,36^{\mathrm{a}}$ & $4,76^{\mathrm{b}}$ & $2,59^{\mathrm{b}}$ & $2,23^{\mathrm{b}}$ & $3,16^{\mathrm{b}}$ & $11,12^{\mathrm{b}}$ \\
\hline $\operatorname{TSS}\left(\mathrm{mg} \mathrm{L}^{-1}\right)$ & $21,43^{\mathrm{a}}$ & $29,14^{\mathrm{a}}$ & $19,53^{\mathrm{a}}$ & $65,17^{\mathrm{a}}$ & $32,23^{\mathrm{a}}$ & $96,02^{\mathrm{a}}$ & $60,14^{\mathrm{b}}$ & $25,54^{\mathrm{b}}$ & $18,18^{\mathrm{b}}$ & $0,40^{\mathrm{c}}$ & $17,47^{\mathrm{b}}$ & $16,75^{\mathrm{b}}$ \\
\hline $\mathrm{SiO}_{2}\left(\mu \mathrm{mol} \mathrm{L}{ }^{-1}\right)$ & $3,75^{\mathrm{a}}$ & $4,73^{\mathrm{a}}$ & $5,76^{\mathrm{a}}$ & $4,77^{\mathrm{a}}$ & $2,87^{\mathrm{a}}$ & $11,38^{\mathrm{a}}$ & $7,28^{\mathrm{a}}$ & $2,91^{\mathrm{b}}$ & $2,51^{\mathrm{b}}$ & $2,45^{\mathrm{b}}$ & $1,22^{\mathrm{b}}$ & $2,89^{\mathrm{b}}$ \\
\hline $\mathrm{PO}_{4}{ }^{3-}\left(\mu \mathrm{mol} \mathrm{L}{ }^{-1}\right)$ & $0,05^{\mathrm{a}}$ & $0,11^{\mathrm{a}}$ & $0,52^{\mathrm{b}}$ & $0,15^{\mathrm{a}}$ & $0,55^{\mathrm{b}}$ & $0,29^{\mathrm{a}}$ & $0,30^{\mathrm{a}}$ & $0,26^{\mathrm{a}}$ & $0,24^{\mathrm{a}}$ & $0,26^{\mathrm{a}}$ & $0,29^{\mathrm{a}}$ & $0,31^{\mathrm{a}}$ \\
\hline $\mathrm{NO}_{2-}\left(\mu \mathrm{mol} \mathrm{L}{ }^{-1}\right)$ & $0,05^{\mathrm{a}}$ & $0,07^{\mathrm{a}}$ & $0,06^{\mathrm{a}}$ & $0,32^{\mathrm{b}}$ & $0,00^{\mathrm{a}}$ & $0,18^{\mathrm{a}}$ & $0,14^{\mathrm{a}}$ & $0,09^{\mathrm{a}}$ & $0,05^{\mathrm{a}}$ & $0,03^{\mathrm{a}}$ & $0,12^{\mathrm{a}}$ & $0,07^{\mathrm{a}}$ \\
\hline
\end{tabular}

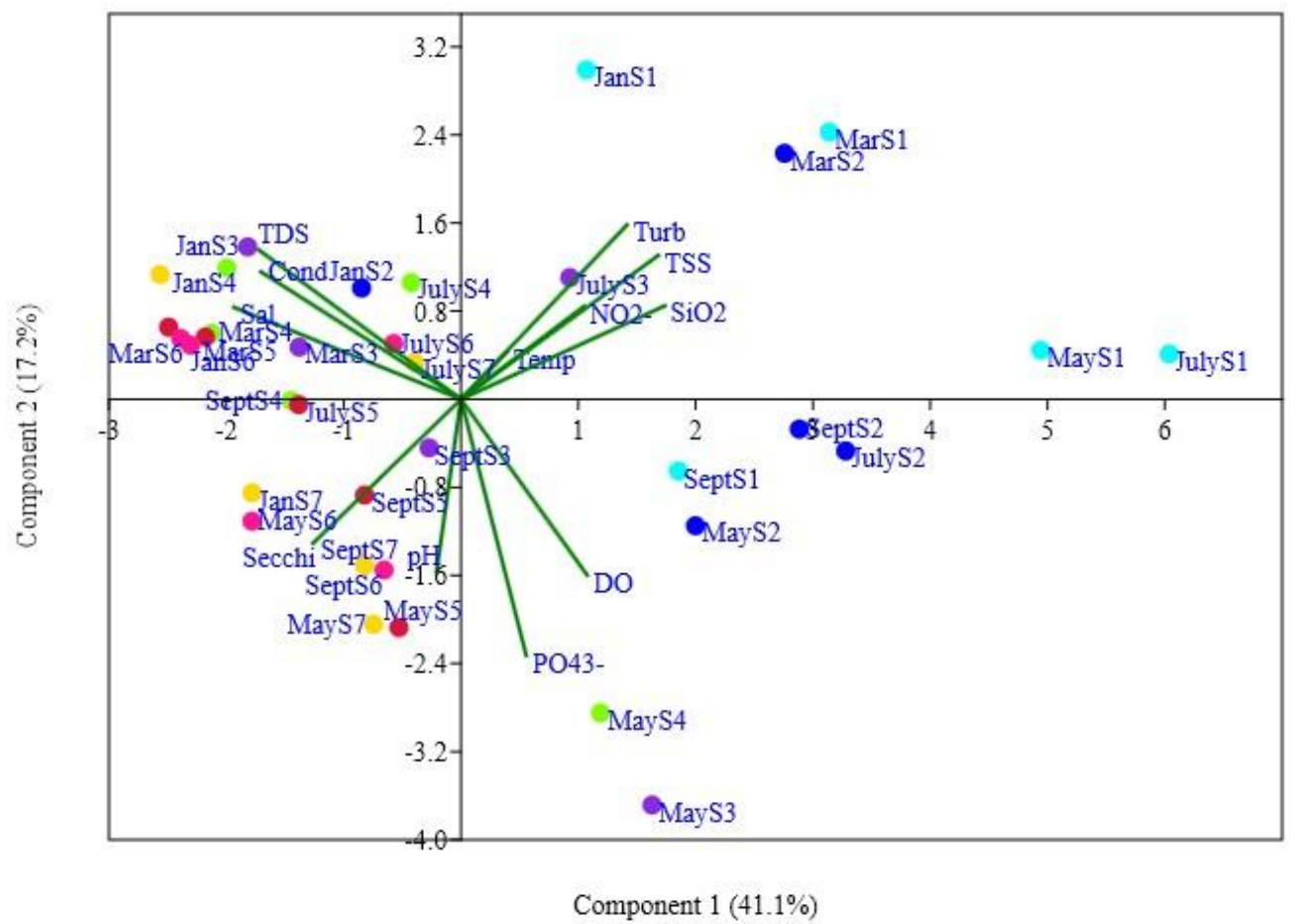

Figure 4. Principal component analysis of environmental variables sampled on Maranhão continental shelf. Turb = turbidity, $T S S=$ total suspended solids, Temp = temperature, $D O=$ dissolved oxygen, Secchi $=$ transparency, Sal $=$ salinity, Cond $=$ conductivity, $T D S=$ total dissolved solids 
In the correlation analysis of the environmental variables (Table 3), salinity, TDS and conductivity had the largest number of significant correlations with other variables and were positively correlated with transparency and negatively correlated with DO, TSS, silicate, phosphate and nitrate. Silicate was negatively correlated with transparency $(\mathrm{r}=-0.53)$ and positively correlated with both turbidity $(\mathrm{r}=0.79)$ and TSS $(\mathrm{r}=0.74)$, confirming the influence of river discharge and rainfall, with higher concentrations of silicate at sites closer to the coast. Nitrite was positively correlated with DO $(r=0.38)$ and TSS $(r=0.57)$, which demonstrates its contribution to the increase in biological activity associated with primary productivity and a greater concentration of particulate matter.

Table 3. Correlation matrix (Pearson's $r$ ) for environmental variables sampled on Maranhão continental shelf. Coefficients in bold denote significant correlations $(p<0.05, t$ test)

\begin{tabular}{c|c|c|c|c|c|c|c|c|c|c|c|c}
\hline Variables & Temp & Sal & TDS & Cond & $\mathbf{p H}$ & DO & Secchi & Turb & TSS & $\mathbf{S i O}_{2}$ & $\mathbf{P O}_{\mathbf{4 3}-}$ & $\mathbf{N O}_{2-}$ \\
\hline Temp & 1.00 & & & & & & & & & & & \\
$\mathrm{Sal}$ & -0.16 & 1.00 & & & & & & & & & & \\
$\mathrm{TDS}$ & -0.03 & $\mathbf{0 . 9 0}$ & 1.00 & & & & & & & & & \\
$\mathrm{Cond}$ & -0.06 & $\mathbf{0 . 9 0}$ & $\mathbf{0 . 8 3}$ & 1.00 & & & & & & & & \\
$\mathrm{pH}$ & 0.17 & 0.03 & -0.02 & 0.02 & 1.00 & & & & & & & \\
$\mathrm{DO}$ & 0.10 & $\mathbf{- 0 . 5 1}$ & $\mathbf{- 0 . 5 2}$ & $\mathbf{- 0 . 4 9}$ & 0.19 & 1.00 & & & & & & \\
$\mathrm{Secchi}$ & -0.14 & $\mathbf{0 . 5 2}$ & $\mathbf{0 . 4 1}$ & $\mathbf{0 . 3 4}$ & 0.22 & 0.03 & 1.00 & & & & & \\
$\mathrm{Turb}$ & 0.07 & $\mathbf{- 0 . 4 1}$ & -0.27 & -0.28 & -0.15 & 0.13 & $\mathbf{- 0 . 5 0}$ & 1.00 & & & & \\
$\mathrm{TSS}$ & 0.16 & $\mathbf{- 0 . 5 7}$ & $\mathbf{- 0 . 4 2}$ & $\mathbf{- 0 . 4 4}$ & -0.24 & 0.24 & $\mathbf{- 0 . 5 2}$ & $\mathbf{0 . 7 7}$ & 1.00 & & & \\
$\mathrm{SiO}_{2}$ & 0.28 & $\mathbf{- 0 . 6 5}$ & $\mathbf{- 0 . 5 2}$ & $\mathbf{- 0 . 5 1}$ & -0.07 & 0.22 & $\mathbf{- 0 . 5 3}$ & $\mathbf{0 . 8 0}$ & $\mathbf{0 . 7 5}$ & 1.00 & & \\
$\mathrm{PO}_{43-}$ & -0.14 & $\mathbf{- 0 . 3 7}$ & $\mathbf{- 0 . 4 6}$ & $\mathbf{- 0 . 3 4}$ & 0.20 & 0.32 & 0.12 & -0.03 & 0.06 & 0.15 & 1.00 & \\
$\mathrm{NO}_{2-}$ & 0.07 & $\mathbf{- 0 . 3 6}$ & -0.28 & -0.33 & -0.11 & $\mathbf{0 . 3 8}$ & -0.13 & 0.30 & $\mathbf{0 . 5 7}$ & 0.31 & -0.31 & 1.00 \\
\hline
\end{tabular}

\section{Discussion}

The distribution of surface temperature in the ocean is approximately zonal and temperature isolines approximately follow latitude parallels, reaching around $28{ }^{\circ} \mathrm{C}$ just north of the equator and diminishing to $-2{ }^{\circ} \mathrm{C}$ at polar latitudes (Pickard and Emery, 1990). Evidence indicates that inter-annual variability in surface water temperature in the tropical Atlantic occurs more due to local dynamics and interactions with the oceanatmosphere interface than external perturbations, such as those caused by the El NiñoSouthern Oscillation (Hameed et al., 1993; Hastenrath and Greischar, 1993).

Eschrique (2011) found that temperatures demonstrated typical characteristics of the northeastern region of Brazil, with high values throughout the year and stability regarding the period and degree of solar radiation in tropical regions. In studies conducted on the continental shelf off the state of Pará on the border with the state of Maranhão, Nogueira Neto (2013) found surface temperatures around $29.50{ }^{\circ} \mathrm{C}$. Silva et al. (2007b) found a temperature of $28.50{ }^{\circ} \mathrm{C}$ in the dry season in an oceanic area adjacent to the Maranhão continental shelf. In studies conducted in the coastal zone of the state of Pará, Martorano et al. (1993) report that high temperatures are typical of equatorial environments, describing a range between $22{ }^{\circ} \mathrm{C}$ and $30{ }^{\circ} \mathrm{C}$ and monthly means ranging from 24 to $28^{\circ} \mathrm{C}$. 
The salinity range is greater in regions that receive with large volumes of river discharge. The influence of the rivers, together with rainfall, are the main factors responsible for the dynamics of the salinity gradient in the region, which is also strongly affected by the discharge from the Amazon river (Silva et al., 2007a; Araujo et al., 2011). Santos et al. (2008) found a range of $2.49 \mathrm{~g} \mathrm{~kg}^{-1}$ to $36.17 \mathrm{~g} \mathrm{~kg}^{-1}$ along the plume of the Amazon River, with lower values in coastal regions closer to the mouth of the river and higher concentrations in areas more distant from the coast, confirming the enormous influence of the Amazon River on equatorial marine waters. Different behavior is found on the Maranhão continental shelf during the dry season, when rivers contribute very little to the fluvial volume. This explains the increase in salinity at sampling stations closer to the coast due to the oceanic characteristics of tropical water. The increase in the evaporation rate, low river input and high surface water temperatures are directly associated with the intrusion of more saline oceanic water on the Maranhão continental shelf (Pontes and El-Robrini, 2008).

The spatial and seasonal distribution of electrical conductivity demonstrated a similar pattern to that found for salinity, which confirms the correlation between these two variables described by Millero (2006), who states that condumetric ratios have the same proportion as salinity, even if the composition of the salts in surface waters differs. Conductivity depends on concentrations of ions and indicates the amount of salts in water, increasing with the increase in the amount of dissolved solids and demonstrating a close relationship with salinity.

With regard to total dissolved solids (TDS), an understanding of the diverse processes involved enables the identification of interferences in hydrodynamics, affecting tide propagation and the dispersion of suspended nutrients and matter from the mainland basin to the ocean (Vilela, 2011). According to Tundisi and Matsumura Tundisi (2008), all minerals in the water are part of the TDS, including non-ionic components and dissolved organic compounds. Therefore, this variable has a direct and proportional correlation with electrical conductivity due to the concentration of ions, as demonstrated in the present study, in which TDS demonstrated quite similar spatial distribution to that found for salinity and conductivity.

The variable $\mathrm{pH}$ is governed by tidal cycles and photosynthesis and/or respiration rates. In aquatic ecosystems, a process of neutralization occurs due to the buffer effect, which maintains $\mathrm{pH}$ in a stable balance, with maximum values obtained in environments with greater salinity (Macêdo et al., 2000). Although no significant spatial differences were found, the $\mathrm{pH}$ was slightly lower at sampling stations closer to the coast, likely due to the input of freshwater, which has more acidic characteristics stemming, above all, from the large quantity of dissolved organic acids, such as sulfuric, nitric, oxalic, acetic and carbonic acids made available by the metabolic interactions of microorganisms in aquatic environments (Esteves, 2011). The gradual increase in $\mathrm{pH}$ toward the open ocean corresponds to carbonate and bicarbonate reactions, which dissociate and increase the alkalinity of surface waters. Santos et al. (2008) found pH values ranging from 7.46 to 8.56 in a transect influenced by the plume of the Amazon River and lower variability in oceanic regions (8.13 to 8.44), which is in agreement with the present study, as $\mathrm{pH}$ demonstrated smaller variations at sampling stations located more distant from the coast.

Carvalho et al. (2016) evaluating the phytoplanktonic composition in the continental shelf of Maranhão, also analyzed several physical and chemical variables, however, with a unique seasonal approach (rainy season and dry season). For the present study, 
the approach was taken on a spatial-temporal scale, however, without necessarily grouping the exclusively rainy and dry months, in order to try to show other influencing factors, for the physical and chemical dynamics on the continental shelf of Maranhão.

According to Millero (2006), this relative stability is characteristic of the Atlantic Ocean, unlike records for the Pacific Ocean, for which a range of 7.2 to 8.2 is described.

In tropical coastal regions, the concentration of dissolved oxygen (DO) in the surface layer is subject to rapid fluctuations influenced by external agents, such as river inputs, rainfall, evaporation, winds and tidal patterns, whereas photosynthetic production can contribute to an increase in DO concentrations in the open ocean (Demaster et al., 1996; Santos et al., 2008; Macêdo et al., 2009). In studies conducted in the region of the Saint Peter and Saint Paul Archipelago within the scope of the REVIZEE [Live Resources of the Exclusive Economic Zone] Program, Becker (2001) found minimum and maximum DO values of 2.56 and $4.41 \mathrm{mg} \mathrm{L}^{-1}$, respectively. DO levels $\leq 4 \mathrm{mg} \mathrm{L}^{-1}$ in natural waters favors anaerobic processes, which produce a large amount of reducing substances that consume a large quantity of the available oxygen for their oxidation (Esteves, 2011).

With regard to suspended particulate matter, the influence of the tide, geomorphology of the coast and outflow bathymetry in shallow coastal environments are determinants of the re-suspension process. In the present study, Stations 1 and 2 were subject to a greater influence of tidal flow, producing higher TSS values, with lower values at sampling stations more distant from the coast. According to Millero (2006), the decrease in the frequency and intensity of the agitation of bottom layers and the emergence of inorganic and biological reactions in oceanic regions lead to a reduction in suspended particulate matter and more stable TSS values. The values found in the present study were higher than those reported by Souza et al. (2003) in the coastal zone of the continental shelf off eastern Brazil. The authors recorded the distribution of suspended solids in two sampling campaigns conducted off the states of Sergipe, Bahia, Espírito Santo and Rio de Janeiro, with TSS values of $13 \mathrm{mg} \mathrm{L}^{-1}$ in the dry season and $90 \mathrm{mg} \mathrm{L}^{-1}$ in the rainy season.

On the Maranhão continental shelf, contrary to the expected behavior, the concentration of TSS was greater in the transition between the rainy and dry seasons, with a maximum value in July 2014. This increase may be explained by the periodic dragging of the canals that offer access to the Itaqui port complex, which invariably redistributes the sediment stored on the bottom to the surface layer, thereby contributing to an increase in the concentration of TSS in regions closer to the coast, which are subsequently transported by tidal currents and/or winds to other compartments of the Maranhão continental shelf.

Suspended solids are directly related to turbidity, water transparency and primary productivity, as a greater amount of TSS results in greater turbidity and lower transparency (Macedo, 2003). An increase in the concentration of TSS exerts a direct influence on the reduction in the rate of photosynthesis due to the extinction of light in the photic zone and exerts an negative impact on the availability of food for some species, leading to an imbalance in the marine food chain. Moreover, suspended sediment can be contaminated with pesticides, heavy metals and other toxic substances, which can have a negative impact on the reproduction of fish and other species (Silva, 2006). Da Silva et al. (2009) found higher turbidity in the coastal zone of Maranhão, evidencing the influence of the estuarine sediment plume and the hydrodynamic energy of tidal forces, with the re-suspension of sediments in the water column leading to a 
turbidity range of 14.80 to 39.29 NTU in the dry season and 55 to $200 \mathrm{NTU}$ in the rainy season.

Dissolved inorganic nutrients (nitrite, phosphate and silicate) were recorded in the present study, as the occurrence of these nutrients indicates mainland inputs that affect primary production in marine environments. The allochthonous origin stems from processes such as atmospheric deposition, the infiltration of ground water by lixiviation, the entrance of marine water in estuaries and the flow of rivers, whereas the internal contribution is based mainly on the benthic and pelagic re-mineralization of organic matter. Understanding nutrient distribution patterns and marine biogeochemical cycles remains a considerable challenge (Conkright et al., 2000). Continental shelves are transition zones between the mainland and ocean with a large supply of particulate and dissolved matter stemming from river discharge (Nittrouer et al., 1995), where complex oceanographic processes co-occur on distinct spatial and temporal scales (Arndt et al., 2011).

The increase in biological activity associated with nutrient availability may be attributed to both biogeochemical processes and other oceanographic processes that cause the re-suspension of organic matter (upwelling, small vortices or internal waves), leading to an increase in biological production (Admiraal et al., 1990; Turner and Rabalais, 1994). Along the continental shelf, the spatial distribution of dissolved nutrients is controlled by vertical and horizontal mixtures caused by tides, waves and wind on the water surface (Sánchez-Arcilla and Simpson, 2002). The synergic action of these variables can cause an increase in dissolved nutrients and total suspended solids, thereby increasing primary production (Mann and Lazier, 1996). In coastal zones of tropical regions, estuarine systems serve as a storage site for suspended nutrients, which then become available to the adjacent continental shelf (Ovalle et al., 1999). For instance, Amazon coastal zone is potentiated by the abundance of mangroves and high hydrodynamic energy, creating a rich supply of dissolved nutrients directed to the continental shelf region (Demaster et al., 1996; Kineke et al., 1996; Nittrouer and Demaster, 1996; Pereira et al., 2010).

On the Maranhão continental shelf, nitrite values were low and very similar among all sampling stations $(\mathrm{F}=0.67 ; \mathrm{p}>0.05)$, which is in agreement with data described by Demaster and Pope (1996) for various transects determined on the continual shelf of the Amazon. Low nitrite values are typical of tropical waters, except when resulting from re-mineralization, re-suspension of the bottom or input from rivers. Santos (2012) confirms this nitrite instability on the continental shelf off the northeastern region of Brazil, with mean values ranging from 0.02 to $0.05 \mu \mathrm{mol} \mathrm{L}^{-1}$, which is characteristic of oligotrophic environments. In the period between the rainy and dry seasons (July 2014), an increase was found in the variation of nitrite concentrations, with a mean of $0.32 \mu \mathrm{Mol} \mathrm{L}{ }^{-1}$. This increase can lead to an increase in biological production rates, a greater availability of suspended matter as well as increases in OD, TSS and turbidity, suggesting an increase in the photosynthetic rate and primary production at stations in oceanic regions. All these aspects contribute to an increase in the production of aquatic organisms in this period in regions more distant from the coast. In contrast, lower values were found in the dry season, as occurred in September 2014, when no nitrate was detected. Therefore, nitrate became more unstable in this period, favoring the development of bacterial oxidation, which increases the availability of ammonia. Pereira et al. (2012) report different behavior in a study conducted in the Amazon 
coastal zone; the authors found mean nitrite values of $0.11 \mu \mathrm{mol} \mathrm{L}-1$ at the end of the rainy season and $0.49 \mu \mathrm{mol} \mathrm{L}^{-1}$ in the dry season.

Phosphate concentrations fluctuate little in tropical estuaries. The mainland is the main source of these nutrients in the marine environment, with concentrations tending to diminish with the distance from the source (Eschrique et al., 2010). Monteiro et al. (2015) report values of $0.11 \mu \mathrm{mol} \mathrm{L}^{-1}$ to $1.08 \mu \mathrm{mol} \mathrm{L}{ }^{-1}$ in an Amazonian estuary near the island of Marajó in the state of Pará. However, Lara and Dittmar (1999) found phosphate concentrations between 1.5 and $5.0 \mu \mathrm{M} \mathrm{L}^{-1}$ in a tidal channel in the municipality of Bragança in the same state. Pereira et al. (2012) found low concentrations (mean: $0.11 \mu \mathrm{mol} \mathrm{L}^{-1}$ in the rainy season and $0.92 \mu \mathrm{mol} \mathrm{L}{ }^{-1}$ in the dry season) in a coastal environment in northeastern Brazil, demonstrating the low influence of seasonality on the final concentration of phosphate in this environment.

The rapid absorption of phosphate in oceanic areas by primary producers and bacteria explain its low concentration and availability. In the present study, concentrations were low at the majority of sampling stations. Ramin et al. (2012) and Eschrique et al. (2006) report that phosphate regeneration processes through remineralization, excretion by zooplankton and absorption by phytoplankton occur at an accelerated rate, making its residence time in oligotrophic waters extremely short (a matter of minutes) and making its particulate form the main compound found in oceanic waters. The coastal region of the Maranhão continental shelf, which is influenced by a large number of mangroves, is an important vehicle for the transport of nutrients to the oceanic region.

Scientific records describe a reduction in the concentration of dissolved nutrients from the estuary to the coastal region, favoring the development of mixture diagrams as a powerful tool for the characterization of nutrient removal processes from masses of water. According to Noernberg (2001), the transport of sediment through the coastal zone reaches an average of 15 nautical miles in the direction of the open sea, with the coastal environment the main redistribution route of nutrients to oceanic regions. Santos et al. (2008) found high nutrient concentrations in the rainy season at a distance of 120 $\mathrm{km}$ from the coast on the continental shelf off the state of Pará, with silicate as the most representative nutrient (range; $14.48 \mu \mathrm{mol} \mathrm{L}^{-1}$ to $108.59 \mu \mathrm{mol} \mathrm{L}^{-1}$ ), confirming the considerable capacity and influence of Amazonian rivers in the distribution of this nutrient to the open ocean. In the present study, silicate demonstrated dispersion capacity through the plume of rivers, thereby reflecting the influence of transport from rivers to oceanic regions of the Maranhão continental shelf and giving this nutrient the greatest capacity for concentration and distribution in the area investigated.

The ordination analysis revealed the influence of river discharge and rainfall on the concentration patterns of different physicochemical variables, which is in agreement with data described by Pereira Filho et al. (2009). Pereira Filho et al. (2003) also report the influence of river discharge on the greater presence of nitrogenated nutrients, which are involved in the nutritional process of phytoplankton. Braga et al. (2008) report that the availability of phosphate is closely linked to the mainland input, with the influence of the Prata River and upwelling in the region of Cape Santa Marta in the state of Santa Catarina (southern Brazil). In the present study, the considerable outflow from the mainland, especially from the Mearim and Pindaré Rivers, and the macrotide conditions, with the capacity to transport nutrients from the mangroves, contributed greatly to the availability of phosphate on the Maranhão continental shelf, with means ranging from $0.05 \mu \mathrm{mol} \mathrm{L}^{-1}$ in January 2014 to $0.55 \mu \mathrm{mol} \mathrm{L}^{-1}$ in September 2014. Braga 
et al. (2008) report similar figures for the Santa Catarina continental shelf, whereas Santos et al. (2008) report lower figures for the Amazon continental shelf.

Silicate is a potential tracer of sediment transported from rivers to oceanic regions, enabling the identification of the distribution caused by this flow (Braga et al., 2008). The analyses also indicate an association between silicate and sampling points closer to the coast, demonstrating negative correlations with salinity, TDS and conductivity, for which higher values were found at more external sampling stations along the Maranhão continental shelf. Ciotti et al. (1995) and Weber et al. (1994) also found a greater concentration of silicate in waters closer to the coast. Braga et al. (2008) describe freshwater and terrestrial inputs along the coast as being major contributors to the high concentrations of silicate on the southern/southeastern continental shelf in summer, which is in agreement with the present findings and demonstrates the importance of climate as a regulating agent for the availability of this nutrient. It is therefore important to maintain the levels of river outflow due to the transport of nutrients to the Maranhão continental shelf, which contribute to biological development as well as the maintenance of trophic, reproductive and developmental aspects of species and, consequently, fishing resources, which have dietary, economic and cultural importance to tropical cities in coastal areas.

\section{Conclusion}

The spatial and temporal variability in the physicochemical variables analyzed (transparency, temperature, salinity, conductivity, dissolved oxygen and suspended solids) is associated with local dynamics governed by river discharge, tidal movements, currents and climatologic events;

Very low salinity was associated with higher concentrations of nutrients, indicating the influence of terrestrial inputs to the Maranhão continental shelf, especially in areas closer to the coast.

Phosphate concentrations were similar throughout the sampling stations and lower than silicate concentrations. In turn, silicate concentrations were significantly higher in areas closer to the Gulf of Maranhão;

The highest nitrite concentrations were found in July 2014, soon after the period of greater rainfall in the region, demonstrating a direct association with mainland inputs and a greater biological production rate, as nitrite values were positively correlated with dissolved oxygen and total suspended solids;

The fluvial transport from the rivers of the state of Maranhão and other freshwater sources in the Amazon region are apparently the major contributors responsible for the maintenance of nutrient availability on the Maranhão continental shelf, where seasonal influences affect phosphate and nitrite availability, with higher concentrations during and soon after the rainy season. In contrast, silicate values are similar throughout the year.

It is recommended in future studies the increase of transects that would be simultaneously sampled to produce maps of the spatial distribution of physicochemical variables from two-dimensional interpolations (2D). 
Acknowledgements. We acknowledge support from FAPEMA (Fundação de Amparo à Pesquisa e ao Desenvolvimento Científico e Tecnológico do Maranhão) and AIRD (Agence Inter-établissements de Recherche pour le Développement) BIOAMAZON project (grants 01739/2013 - AIRD_GUYMAZ). We also acknowledge the support of the Departamento de Oceanografia e Limnologia (DEOLI, UFMA) for kindly providing reagents and spectrophotometer time for nutrient analysis. In addition, we wish to thank two anonymous reviewers for constructive comments on the MS.

\section{REFERENCES}

[1] Admiraal, W., Breugem, P., Jacobs, D. M. L. H. A., De Ruyter Van Steveninck, E. D. (1990): Fixation of dissolved silicate and sedimentation of biogenic silicate in the lower river Rhine during diatom blooms. - Biogeochemistry 9(2): 175-185.

[2] Araujo, M., Limongi, C., Servain, J., Silva, M., Leite, F. S., Veleda, D., Lentini, C. A. D. (2011): Salinity-induced mixed and barrier layers in the southwestern tropical Atlantic Ocean off the northeast of Brazil. - Ocean Science 7: 63-7.

[3] Arndt, S., Lacroix, G., Gypens, N., Regnier, P., Lancelot, C. (2011): Nutrient dynamics and phytoplankton development along an estuary-coastal zone continuum: A model study. - Journal of Marine Systems 84(3-4): 49-66.

[4] Becker, H. (2001): Hidrologia da região de bancos e ilhas oceânicas do nordeste brasileiro. Uma contribuição ao programa REVIZEE. - Doctoral Thesis, Postgraduate Program in Ecology and Natural Resources, Universidade Federal de São Carlos, São Carlos.

[5] Braga, E. S., Chiozzini, V. C., Berbel, G. B. B., Maluf, J. C. C., Aguiar, V. M. C., Charo, M., Molina, D., Romero, S. I., Eichler, B. B. (2008): Nutrient distribution over the southwestern South Atlantic continental shelf from Mar Del Plata (Argentina) to Itajaí (Brazil): Winter-summer aspects. Brazil. - Continental Shelf Research 28: 1649-1661.

[6] Carvalho, R. C. Q., Cutrim, M. V. J., Eschrique, S. A., Azevedo-Cutrim, A. C. G. Moreira, E. G., Silveira, P. C. A., Coêlho, J. M. (2016): Microphytoplankton composition, chlorophyll-a concentration and environmental variables of the Maranhão Continental Shelf, Northern Brazil. - Lat. Am. J. Aquat. Res. 44(2): 256-266. DOI: 10.3856/vol44-issue2-fulltext-7.

[7] Ciotti, A. M., Odebrecht, C., Fillmann, G., Möller Jr., O. O. (1995): Freshwater outflow and subtropical convergence influence on phytoplankton biomass on the southern Brazilian continental shelf. - Continental Shelf Research 15: 1737-1756.

[8] Conkright, M. E., Gregg, W. W., Levitus, S. (2000): Seasonal cycle of phosphate in the open oceano. - Deep Sea Research I 47: 159-175.

[9] Da Silva, I. R., Pereira, L. C. C., Guimarães, D. O., Trindade, W. N., Asp, N., Costa, R. M. (2009): Environmental Status of Urban Beaches in São Luís (Amazon Coast, Brazil). - Journal of Coastal Research 56: 1301-1305.

[10] Demaster, D. J., Pope, R. H. (1996): Nutrient dynamics in Amazon shelf waters: results from amassed. - Continental Shelf Research 16(3): 263-289.

[11] Demaster, D. J., Smith Jr., W. O., Nelson, D. M., Aller, J. Y. (1996): Biogeochemical processes in Amazon shelf waters: chemical distributions and uptake rates of silicon, carbon and nitrogen. - Continental Shelf Research 16(5/6): 617-643.

[12] El-Robrini, M., Marques Jr., V., Silva, M. M. A., El-Robrini, M. H. S., Feitosa, A. C., Tarouco, J. E. F., Santos, J. H. S., Viana, J. R. (2006): Pará. - In: Muehe, D. (ed.) Erosão e Progradação do Litoral Brasileiro, Ministério do Meio Ambiente, Brasília.

[13] Eschrique, S. A. (2011): Estudo do balanço biogeoquímico dos nutrientes principais como indicador da influência antrópica em sistemas estuarinos do nordeste e sudeste do Brasil. - Doctoral Thesis, Postgraduate Program in Chemical and Geological Oceanography, Universidade de São Paulo, São Paulo-SP. 
[14] Eschrique, S. A., Santos, M. L. S., Saraiva, A. L. L., Delfino, I. B., Botelho, V. F. (2006): Estudo dos nutrientes no ambiente pelágico adjacente à costa do Estado do Pará. Arquivos de Ciências do Mar 39: 120-130.

[15] Eschrique, S. A., Braga, E. S., Marins, R. V., Chiozzini, V. G. (2010): Nutrients as indicators of environmental changes in two Brazilian estuarine systems. - Shewc 2010 $\mathrm{X}$ Safety, Health and Environment World Congress Converging Towards Sustainability 10: 71-75.

[16] Esteves, F. A. (2011): Fundamentos de Limnologia. - Editora Interciência/FINEP, Rio de Janeiro.

[17] Grasshoff, K., Kremling, K., Ehrhardt, M. (1999): Methods of Seawater Analysis. Wiley-Verlag Chemie, Weinheim.

[18] Hameed, S., Sperber, K. R., Meinster, A. (1993): Teleconnections of the Southern Oscillation in the tropical Atlantic sector in the OSU coupled upper ocean-atmosphere GCM. - Journal of Climate 6: 487-798.

[19] Hammer, Ø., Harper, D. A. T., Ryan, P. D. (2001): PAST: Paleontological Statistics Software Package for Education and Data Analysis. - Palaeontologia Electronica 4: 1-9.

[20] Hastenrath, S., Greischar, L. (1993): Further work on the prediction of Northeast Brazil rainfall anomalies. - Journal of Climate 6: 743-758.

[21] Jackson, D. A. (1993): Stopping rules in principal components analysis: a comparison of heuristical and statistical approaches. - Ecology 74: 2204-2214.

[22] Jennerjahn, T. C., Knoppers, B. A., Souza, W. F. L., De Carvalho, C. E. V., Mollenhauer, G., Hubner, M., Ittekkot, V. (2010): The Tropical Brazilian Continental Margin. - In: Liu, K.-K., Atkinson, L., Quinones, R., Talaue-Mcmanus, L. (eds.). Carbon and Nutrient Fluxes in Continental Margins: A Global Synthesis. Springer Verlag, Heidelberg, Berlin.

[23] Kineke, G. C., Sternberg, R. W., Trowbridge, J. H., Geyer, W. R. (1996): Fluid mud processes on the Amazon continental shelf. - Continental Shelf Research 16: 667-696.

[24] Lara, R. J., Dittman, T. (1999): Nutrient dynamics in a mangrove creek (North Brazil) during the dry season. - Mangroves Salt Marshes 3(3): 185-195.

[25] Lefèvre, N., Dias, F. J. S., Torres Jr, A. R., Noriega, C., Araújo, M., Castro, A. C. L., Rocha, C., Jiang, S., Ibánhez, J. S. P. (2017): A source of $\mathrm{CO}_{2}$ to the atmosphere throughout the year in the Maranhense continental shelf ( $2^{\circ} 30^{\prime} \mathrm{S}$, Brazil). - Continental Shelf Research 141: 38-50.

[26] Macedo, J. A. B. (2003): Métodos Laboratoriais de Análises Físico-Químicas e Microbiológicas. - Conselho Regional de Química, Belo Horizonte.

[27] Macêdo, S. J., Flores-Montes, M. J., Lins, I. C. (2000): Características abióticas da área. In: Barros, H. M., Eskinazi-Leça, E., Macêdo, S. J., Lima, T. (eds.) Gerenciamento participativo de estuários e manguezais. Editora Universitária da UFPE, Recife.

[28] Macêdo, S. J., Flores-Montes, M. J., Costa, K. M. P. (2009): Condições hidrológicas da Zona Econômica Exclusiva (ZEE) do Nordeste do Brasil. - In: Hazin, F. H. V (ed.). Meteorologia e Sensoriamento Remoto, Oceanografia Física, Oceanografia Química e Oceanografia Geológica (Programa REVIZEE-SCORE Nordeste, V. 1). Editora Martins e Cordeiro, Fortaleza.

[29] Mann, K. H., Lazier, J. R. N. (1996): Dynamics of Marine Ecosytems: BiologicalPhysical Interactions in the Oceans. - Blackwell Science, Oxford, Cambridge.

[30] Martorano, L. G., Pereira, L. C., Cezar, E. G. M., Pereira, I. C. B. (1993): Estudos climatológicos do Estado do Pará, classificação climática (Köppen) e deficiência hídrica (Thornthwhite, Mather). - SUDAM/EMBRPA, SNLCS, Belém.

[31] Millero, F. J. (2006): Chemical Oceanography. - CRC Press, Boca Raton, FL.

[32] Mochel, F. R., Ponzoni, F. J. (2007): Spectral characterization of mangrove leaves in the Brazilian Amazonian Coast: Turiaçu Bay, Maranhão State. - Anais da Academia Brasileira de Ciências 79: 683-692.

[33] Monteiro, S. M., El-Robrini, M., Alves, I. C. C. (2015): Dinâmica Sazonal de Nutrientes em Estuário Amazônico. - Mercator 14(1): 151-162. 
[34] Nikiema, O., Devenon, J. L., Baklouti, M. (2007): Numerical modeling of the Amazon River plume. - Continental Shelf Research 27(7): 873-899.

[35] Nittrouer, C. A., Demaster, D. J. (1996): The Amazon shelf setting tropical, energetic, and influenced by a large river. - Continental Shelf Research 16: 553-574.

[36] Nittrouer, C. A., Brunskill, G. J., Figueiredo, A. G. (1995): Importance of tropical coastal environments. - Geo-Marine Letters 15(3-4): 121-126.

[37] Noernberg, M. A. (2001): Processos morfodinamicos no complexo estuarino de Paranaguá. Paraná, Brasil: um estudo a partir de dados in situ e Landsat-TM. - Doctoral Thesis, Postgraduate Program in Geology, Curitiba, Brazil.

[38] Nogueira Neto, A. V. (2013): Variabilidade da Corrente Norte do Brasil associada aos padrões termohalinos na borda da Plataforma Continental Norte do Brasil. - Master's Dissertation, Postgraduate Program in Oceanography, Universidade Federal de Pernambuco, Recife.

[39] Ovalle, A. R. C., Rezende, C. E., Carvalho, C. E. V., Jennerjahn, T. C., Ittekkot, V. (1999): Biogeochemical characteristics of coastal waters adjacent to small rivermangrove systems, East Brazil. - Geo-Marine Letters 19(3): 179-185.

[40] Pereira Filho, J., Spillere, L. C., Schettini, C. A. F. (2003): Dinâmica de nutrientes na região portuária do estuário do Rio Itajaí-Açu, SC. - Atlântica 25(1): 11-20.

[41] Pereira Filho, J., Rörig, L. R., Hesse, K., Poremba, K., Schettini, C. A. F., Proença, L. A., Santos, J. E. (2009): Primary and bacterial production processes in the lower Itajaí-Açú estuary, Santa Catarina, Brazil. - Brazilian Journal of Aquatic Science and Technology 13(1): 1-10.

[42] Pereira, L. C. C., Monteiro, M. C., Guimarães, D. O., Matos, J. B., Costa, R. M. (2010): Seasonal effects of wastewater to the water quality of the Caeté river estuary, Brazilian Amazon. - Anais da Academia Brasileira de Ciências 82(2): 467-478.

[43] Pereira, L. C. C., Silva, N. I. S., Costa, R. M., Asp, N. E., Costa, K. G., Vila-Concejo, A. (2012): Seasonal changes in oceanographic processes at an equatorial macrotidal beach in northern Brazil. - Continental Shelf Research 43: 95-106.

[44] Pickard, G. L., Emery, W. J. (1990): Descriptive Physical Oceanography: An Introduction. - Pergamon Press, New York.

[45] Pontes, P. H. P., El-Robrini, M. (2008): Massa d'água da plataforma continental do Maranhão, durante o período seco (novembro, 1997). - Boletim do Laboratório de Hidrobiologia 21: 17-24.

[46] Ramin, M., Perhar, G., Shimoda, Y., Arhonditsis, G. B. (2012). Examination of the effects of nutrient regeneration mechanisms on plankton dynamics using aquatic biogeochemical modeling. - Ecological Modelling 240: 139-155.

[47] Sánchez-Arcilla, A., Simpson, J. H. (2002): The narrow shelf concept: couplings and fluxes. - Continental Shelf Research 22(2): 153-172.

[48] Santos, D. H. C. (2012): Estrutura da comunidade fitoplanctônica em recifes artificiais da plataforma continental de Pernambuco, Brasil. - Doctoral Thesis, Postgraduate Program in Oceanography, Universidade Federal de Pernambuco, Recife.

[49] Santos, M. L. S., Muniz, K., Barros-Neto, B., Araújo, M. (2008): Nutrient and phytoplankton biomass in the Amazon River shelf waters. - Anais da Academia Brasileira de Ciências 80(4): 703-717.

[50] Silva, A. C. D., Araújo, M., Pinheiro, L. D. S. (2007b): Caracterização hidrográfica da plataforma continental do maranhão a partir de dados oceanográficos medidos, remotos e modelados. - Revista Brasileira de Geofísica 25(3): 281-293.

[51] Silva, A. C., Araújo, M., Bourlès, B. (2007a): Seasonal variability of the Amazon River plume during REVIZEE Program. - Tropical Oceanography 1: 1-22.

[52] Silva, H. L. G. (2006): Modelagem Bidimensional do Fósforo com Vistas a Gestão de Bacias Hidrográficas - Estudo de Caso: Reservatório de Fiú, Paraná. - Masters Dissertation, Postgraduate Program in Water and Environmental Engineering, Universidade Federal do Paraná, Curitiba. 
[53] Silva, L. C. F., Alvarenga, J. B. R. (1994): Levantamento do estado da arte dos recursos vivos marinhos do Brasil: Oceanografia Física da Região Nordeste. - Ministério do Meio Ambiente dos Recursos Hídricos e da Amazônia Legal, Programa REVIZEE, Brasília.

[54] Silva, M. H. L., Torres-Júnior, A. R., Castro, A. C. L., Azevedo, J. W., Ferreira, C. F. C., Cardoso, R. L., Nunes, J. L. S., Carvalho-Neta, R. N. F (2018): Fish assemblege structure in a port region of the Amazonic coast. - Iheringia 108(2018018): 1-11.

[55] Souza, W. F. L., Knoppers, B., Balzer, W., Leipe, T. (2003): Geoquímica e fluxos de nutrientes, ferro e manganês para a costa leste do Brasil. - Geochimica Brasiliensis 17(2): 130-144.

[56] Stramma, L., Schott, F. (1999): The mean flow field of the tropical Atlantic Ocean. Deep Sea Research 46(1-2): 279-303.

[57] Strickland, J. D. H., Parsons, T. R. (1972): A Practical Handbook of Seawater Analysis. Fisheries Research Board of Canada Bulletin, Ottawa.

[58] Tundisi, J. G., Matsumura Tundisi, T. (2008): Limnologia. - Oficina de Textos, São Paulo.

[59] Turner, R. E., Rabalais, N. N. (1994): Coastal eutrophication near the Mississippi River delta. - Nature 368(6472) 619-621.

[60] Vilela, C. P. X. (2011): Influência da hidrodinâmica sobre os processos de acumulação de sedimentos finos no estuário do rio Amazonas. - Doctoral Thesis, Postgraduate Program in Ocean Engineering, UFRJ/COPPE, Rio de Janeiro.

[61] Weber, R. R., Knoppers, B. A. E Fillmann, G. (1994): Oceanografia Química. - In: Valentin, J. L., Gaeta, S. A., Spach, H. L., Montú, M. A., Odebrecht, C. Diagnóstico ambiental oceânico e costeiro das regiões sul e sudeste do Brasil, Petrobras - Petróleo Brasileiro, Rio de Janeiro.

[62] Zar, J. H. (2010): Biostatistical Analysis. - Pearson Prentice Hall, New Jersey. 